\title{
Crawford v. Washington, Revisited Confrontation Or Not, Don't Forget To Duck, Man
}

Patrick J. Reville, Iona College, USA

\begin{abstract}
Picture this: It's Friday afternoon, the day after Thanksgiving, Black Friday for those in retail. You are relaxed and confident. Your tenure application at the university has so far sailed through without a hitch. It seems that all that publishing you have done has kept you from perishing, academically, that is. A knock comes to your faculty office door, and two suits flashing tin enter. They are from the Organized Commission for Reparations in Academic Plagiarism, otherwise known as: OCRAP. A somewhat obscure quasi-federal agency set up under the Carter Administration, a visit from them often spells academic doom. It seems that they have received a bevy of unsolicited e-mails accusing you of the academically unforgivable offence of using other researchers' material without attribution. You ask the key question: "WHO?" Their response is that that information is confidential, and unavailable to you. They serve you with a notice that a hearing will be held before Christmas, at the U. S. Courthouse, Foley Square, New York, N. Y. Your first reaction is that you need to contact a lawyer. Ironically, you quickly realize, that you are a lawyer. Something in the back of your mind tells you that you have to have the ability to confront your accusers; something perhaps in the Constitution? Maybe the time is ripe to go back and revisit the "confrontation" aspect of your present situation.
\end{abstract}

Keywords: Sixth Amendment, Confrontation, Crawford

\section{INTRODUCTION}

\section{Don't Forget to Duck, Man}

C $\mathrm{t}$ was a typical morning in Brooklyn Criminal Court, Trial Part in 1996, when a defendant by the name of Benito Oliver appeared before Judge Lorin Duckman for trial on a simple assault/harassment charge. The defendant stood accused of, among other things, threatening to do harm to the complaining witness. A Temporary Order of Protection had been issued, and high bail requested by the People had been set prior. The case had started out as a felony, but the People, electing not to go to a Grand Jury, had reduced the charges to a misdemeanor. The People had, on two (2) prior occasions, failed to be prepared to proceed to trial. Defense Counsel moved for a bail reduction, and, naturally, the People opposed. Judge Duckman had dealt with literally thousands of such cases in his five (5) years on the bench. He knew that many, if not most, such cases eventually got reduced to and disposed of with pleas to Violations, with little or no jail time imposed. So, borrowing from a page in the book written by Judge Bruce ("Cut Him Loose, Bruce") Wright, who clearly did not believe in preconviction preventive detention by unreasonable bail, Judge Duckman granted the defense counsel's request, and set what he thought was a reasonable bail that apparently was makeable, and admonished the defendant to stay away from the alleged victim. Next case.

Within a matter of three (3) weeks, the defendant, having made the reduced bail, made good on his threats, and murdered the complaining witness. He then took his own life as well. Judge Duckman was vilified in the New York Press, gained national recognition for what was wrong with our domestic violence court proceedings, and was 
eventually removed from the bench. Some said that there were two tragedies resulting from this case: the senseless, potentially avoidable death of another victim of domestic violence, and the destruction of the judicial career of a sitting jurist.

As a result of what became known as "The Duckman Case" judges throughout at least the New York area began taking a much less lenient approach regarding bail in domestic violence cases, and the issuance of Orders of Protection in such matters, with some say extreme restrictions on access to a complaining witnesses (spouse, girlfriend, and even the children of the parties) became commonplace. No judge with half a brain was going to be even accused of "Doing a Duckman."

Fast forward to a later case in Westchester County, N. Y., involving the alleged physical abuse and threatening of a spouse by the common law husband. The victim called 911 to report an incident wherein her husband came home drunk, again, fought with her, and threatened her with a machete. Naturally, the police were dispatched and rolled to the residence. Upon arrival, the woman answered the door, and somewhat calmly told the responding officers what the husband had done. There were no apparent signs of injury, and the woman refused medical attention. There was no visible sign of an altercation at the premises. The husband was asleep on the bed in a room adjacent to the living room. There was a machete in that room, but it was an ornate, souvenir type implement, and it was hanging in a scabbard by a wall mount. The woman told the police that she had been attacked by her machete wielding husband, and that she wanted him arrested.

The police woke the man from a dead sleep and arrested him. Initially charged with felony assault and weapons charges, a Temporary Order of Protection was issued barring the man from the marital residence, and barring him from contact with his wife and children. Bail was set so high that the defendant, a day laborer, could never make same. No Judge Duckman repeat here. As a result, he sat in jail awaiting disposition of the case. The case was sent up to the Westchester County Integrated Domestic Violence Part in White Plains, N. Y. From the outset of Court proceedings, it appeared that the victim/complaining witness spouse had a change of heart. She told the Court, the District Attorney's office, The Victim Advocate's Office and the defense counsel that she did not want to proceed with the case. She wanted her husband home; she could not support herself and her children. Although the case was reduced to a misdemeanor, apparently as a result of the victim's non-cooperation, the prosecutor would not budge from the offer of a misdemeanor plea. The defendant, in jail pre-trial unable to make bail, was faced with the dilemma: cop a plea to a crime he said he did not commit, and get out on probation, or stay in jail and wait for a trial. In the midst of this, the victim spouse recanted, in writing, her story of assault and menacing. It seems she had gotten sick and tired of her husband's drinking and carousing, and she had warned him she would fix his wagon good and proper if she ever caught him again. So, when he stayed too long at Rosa's Cantina that fateful night, she had him arrested. She said she was sorry, he had never attacked her, and she would not proceed with the case. This, at first, seemed like music to the defendant's and his lawyer's ears. The case surely would get withdrawn/dismissed. Not so fast, was the position of the prosecutor. The People were prepared to go forward with the prosecution regardless of the recantation, and they would subpoena the victim and force her to testify, if necessary. No Duckman Scenario here.

The victim, faced with eviction for non-payment of rent, and having no income, her husband in jail, took her children and went back to her native country south of the border. Again, without a complaining witness, it appeared that the case would fold. Not so. The case was scheduled for a non-jury trial (the quickest was to bring the case to a head). Without a complaining witness (the same complaining witness that had recanted her story) the People's case would surely be deficient at trial. There were no witnesses to nor proof of the alleged assault. Not so, said the prosecutor. The 911 tape and the statement(s) made to the arresting officers would be used.

At trial, the defense argued Hearsay as grounds for excluding the 911 tape and the conversation with the officer at the home. Over objection by defense counsel, both the 911 tape and the statement at the scene were allowed into evidence. The Hearsay exception of "excited utterance" was cited as the grounds for allowance of the "evidence". Despite no testimony by the victim, no witnesses to the alleged attack and no proof of injury, the defendant was convicted of a misdemeanor solely on the basis of the 911 tape and the oral statements to the officers. Parenthetically, the written, sworn to and notarized recantation by the "victim" was not allowed into evidence, because the prosecutor successfully argued that it was Hearsay, an out of court statement that was not subject to 
cross examination! Although the defendant did not receive the maximum sentence of one (1) year in jail, he had already served numerous months in jail awaiting disposition. He did not elect to appeal his conviction; he just wanted out of jail, and to put as much distance between himself and law enforcement as possible. It was reported to defense counsel that the defendant also had headed for the border upon his release.

How could such a conviction be possible under the stated circumstances? What ever happened to the right of confrontation under the Sixth Amendment of the Constitution? "Excited Utterance" was the apparent answer. Could this be correct? Is that the law of the land? In the wake of Judge Duckman's downfall, had the Sixth Amendment somehow been trumped?

\section{UNITED STATES CONSTITUTION AMENDMENT VI}

"In all criminal prosecutions, the accused shall enjoy the right to a speedy and public trial, by an impartial jury of the state and district wherein the crime shall have been committed; which district shall have been previously ascertained by law, and to be informed of the nature and cause of the accusation; to be confronted with the witnesses against him; to have compulsory process for obtaining witnesses in his favor, and to have the Assistance of Counsel for his defense." (1)

\section{CRAWFORD V. WASHINGTON (2)}

The "right to confrontation" clause was dealt with, to say the least, by the U. S. Supreme Court in the Crawford case in 2004. In that case, Michael Crawford admittedly stabbed a man in a dispute regarding a prior attempted rape by the victim of Crawford's wife, Sylvia. Crawford claimed self-defense. Both Crawford and his wife gave statements to the police. At issue was Crawford's wife's statement that seemed to possibly nullify the self-defense aspect of her husband's actions. At trial, Sylvia refused to testify, claiming spousal privilege, but the People, over objection, introduced the wife's statement as evidence. The defense objected on the grounds of Hearsay, but the statement was in fact admitted. Crawford was convicted, and the State Supreme Court affirmed. Crawford appealed to the U. S. Supreme Court.

In a virtually unanimous decision, the U. S. Supreme Court reversed Crawford's conviction, and remanded it back down below, relying on the Confrontation Clause of the Sixth Amendment. Mr. Justice Scalia delivered the opinion of the court, which was joined in by Justices Kennedy, Stevens, Thomas, Souter, Breyer and Ginsberg. (Then) Chief Justice Renquist filed a concurring opinion, in which (then) Justice O'Connor joined.

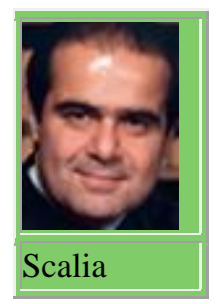

Decision: 9 votes for Crawford, 0 vote(s) against Legal provision: Right to Confront and Cross-Examine, Compulsory Process Full Opinion by Justice Antonin Scalia

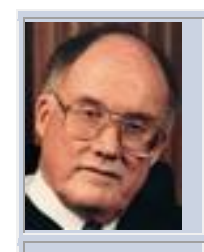

Rehnquist

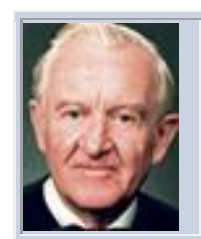

Stevens
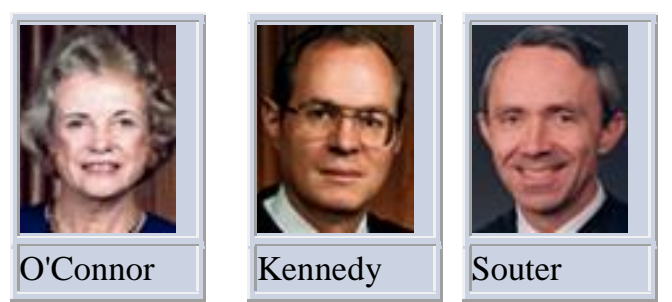
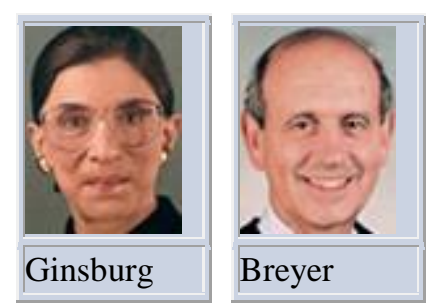

Source: The Oyez Project 
By its opinion in Crawford, the Court moved away from its 1980 decision in Ohio v. Roberts (3), which had held that the right of confrontation did not bar the use of a statement of an unavailable witness against a defendant if the statement bore an "indicia of reliability" which could be met by falling within a "firmly rooted hearsay exception" or bore a "particularized guarantee of trustworthiness."(4) Defendant Crawford argued that the standard in Roberts strayed from the original meaning of the Constitution. Justice Scalia agreed.

Justice Scalia relied not only on the strict text of the Amendment, but also on the historical background of the protection. His decision takes a reader back to Roman times and English common law, through numerous declarations of rights by the colonies in revolutionary days, and state statutes and decisions over the years. His conclusion is that the protections under the Confrontation Clause apply to more than in-court testimony; that out-ofcourt statements are clearly within the parameters of protection. However, Justice Scalia did leave a door open regarding nontestimonial hearsay:

"Where nontestimonial hearsay is at issue, it is wholly consistent with the Framers' design to afford the States flexibility in their development of hearsay law... as would an approach that exempted such statements from Confrontation Clause scrutiny altogether. Where testimonial evidence is at issue, however, the Sixth Amendment demands what the common law required: unavailability and a prior opportunity for cross examination. We leave for another day any effort to spell out a comprehensive definition of "testimonial."(5)

Justice Scalia was accurate in his prediction of "another day", as can be seen below.

\section{POST CRAWFORD DEVELOPMENTS}

\section{The Duckman Scenario}

In the lingering wake of the Duckman case, since no judge wants to be the next face on a judicial misconduct milk carton, judges have routinely tried to formulate distinctions from Crawford, particularly in domestic violence cases. As a further result of such would-be hair splitting by jurists, the standard position of many prosecutors has been that the statements made by victims, who later decline/refuse to testify, are not testimonial in nature, and therefore are not subject to Crawford's Confrontation rule. Hence, often prosecutors take the position that they don't need a victim's actual testimony at trial to secure a conviction, particularly when a 911 tape of an alleged attack is available.

\section{Davis v. Washington (6)}

Davis v. Washington actually decided two cases that had made their respective ways to the U. S. Supreme Court on the confrontation issue, one involving defendant Davis from Washington, and the other involving defendant Hammon from Indiana. In the "Davis" part of the decision, at issue was a 911 call from an alleged victim, reporting an attack on her by one Adrian Davis. The victim did not appear nor testify at trial, and Davis was convicted primarily on the basis of the introduction of the 911 tape.

In the "Hammon" portion of the case, police responded to a report of a domestic disturbance, and found no apparent ongoing dispute/altercation. The "victim" at first denied that anything was amiss. However, statements made by the victim shortly thereafter were used at trial, but again, the victim did not appear nor testify. Hammon was also convicted, based on the statements only.

Once again, Mr. Justice Scalia delivered the opinion of the Court. In short, Justice Scalia concluded that the statement (911 tape) in the Davis portion was not testimonial (therefore, its use was not necessarily in violation of the Confrontation Clause), whereas, the statements in the Hammon portion were testimonial (and therefore were subject to the protections of the Clause). Justice Scalia wrote:

"Without attempting to produce an exhaustive classification of all conceivable statements in response to police interrogation - as either testimonial or nontestimonial, it suffices to decide the present cases to hold as follows: Statements are nontestimonial when made in the course of police interrogation under circumstances objectively indicating that the primary purpose of the interrogation is to enable police assistance to meet an ongoing 
emergency. They are testimonial when the circumstances objectively indicate that there is no such ongoing emergency, and that the primary purpose of the interrogation is to establish or prove past events potentially relevant to later criminal prosecution." (7)

Having said this, it is not to be concluded because of Davis' conviction, however, that all 911 taped conversations are nontestimonial, for if the purpose or nature of the 911 exchange is fact-finding and/or reporting of a (past) non-emergency situation/ event, the same would in fact take on testimonial character.

\section{Post Davis}

As pointed out in the March, 2007 edition of The Champion, the official magazine of the National Association Of Criminal Defense Lawyers, the Supreme Court had at that point followed Davis since its issuance, in nine cases where it granted certiorari, vacated convictions and remanded for further proceedings on the Davis principles, formulating the premise/conclusion that in determining when the emergency-resolving, non-testimonial statements to officers would be allowed despite the inability to confront, the following limits would be: (a) The statements must involve an objective, ongoing, actual emergency, as opposed to fact finding of past events; (b) possible danger to the general public due to a would-be defendant at large will not trigger an "emergency"; and, (c) objective analysis of an officer's inquiry and a witness's statement(s) must relate to resolving the particular pending emergency, and not a stretch in acquiring information for broader purposes. (8)

As a further note, Crawford was ruled not retroactive to cases that were final before that ruling was issued in March of 2004. (9)

\section{Melendez-Dias v. Massachusetts (10)}

In 2009, the Supreme Court again addressed the Confrontation issue. In 2001, one Luis Melendez-Diaz was charged with trafficking cocaine in Boston. At his trial, no testimony was admitted into evidence of any lab analyst or technician as to the drugs, the prosecution relying instead, over defendant's objection, on lab reports to prove the character of the substances placed into evidence. Melendez-Diaz was convicted, and his State Court appeals in Massachusetts were to no avail. Sentenced to three years in jail and three years probation, MelendezDiaz got his case before the U.S. Supreme Court.

The issue before the Court was whether a governmental analyst's lab report prepared for use in a criminal prosecution was "testimonial" in nature, and therefore subject to the requirements of the "confrontation clause" of the Sixth Amendment as decided in Crawford.

In a 5-4 decision, Justice Scalia found that denying Melendez-Diaz the opportunity to confront the person or persons who had performed the analysis of the substance seized, and allowing the prepared report of same into evidence was a violation of the defendant's Sixth Amendment right of confrontation. Justice Scalia was joined by Justices Ginsberg, Stevens, Souter and Thomas. Dissenting were Justices Kennedy, Roberts, Alito and Breyer.

\section{CONCLUSIONS}

1. The Duckman Syndrome is still alive and well in the minds of judges, prosecutors and attorneys practicing in the criminal courts.

2. Crawford has been a breath of fresh air since 2004 for the proponents of the confrontation protections of the Sixth Amendment.

3. Davis (since 2006) has clarified the definition of "testimonial" in the confrontation field, and the U. S. Supreme Court, if anything, has been clear in sending a message that it does not intend to allow prosecutorial end runs on its interpretation.

4. Melendez-Diaz (2009) has once again re-solidified the confrontation clause interpretation of the Court. 


\section{AUTHOR INFORMATION}

Patrick J. Reville, B.B.A., J.D., earned his B.B.A. degree in Accounting from Iona College, New Rochelle, New York, in 1965, and the Juris Doctor degree from the Fordham University School Of Law in 1968. He Joined the Iona College faculty in 1975, and is presently an Associate Professor of Business Law there. Attorney Reville has practiced law and accounting in Westchester County, New York, for forty (40) years, and presently devotes his practice time to Criminal Law, Small Businesses, Real Estate and Estates.

\section{FOOTNOTES}

1. U.S. CONST. amend. VI.

2. 124 S.Ct. 1354 (2004).

3. 448 U.S. 56 (1980).

4. Id., at 66 .

5. Crawford v. Washington, 124 S.Ct. 1354, 1374.

6. 126 S.Ct. 2266 (2006).

7. Id., at 2273, 2274.

8. Timothy O'Toole and Catharine Easterly, Davis v. Washington: Confrontation Wins The Day, CHAMPION, National Association Of Criminal Defense Lawyers, March, 2007, at 20.

9. Whorton v. Bockting, 127 S.Ct. 1173 (2007).

10. Melendez-Diaz v. Massachusetts, 129 S.Ct. 2527, 174 L.Ed. 314 (2009). 